\title{
PD 118,576: A NEW ANTITUMOR MACROLIDE ANTIBIOTIC
}

\author{
John H. Wilton, Gerard C. Hokanson and James C. French \\ Warner-Lambert/Parke-Davis Pharmaceutical Research \\ Ann Arbor, Michigan 48105, U.S.A.
}

(Received for publication August 9, 1985)

\begin{abstract}
The isolation and properties of PD 118,576, a new cytotoxic antibiotic obtained from the culture broth of a Streptomyces sp., are described. The structure of this compound was established by spectral analyses of the parent compound and its tri- $O$-acetyl derivative. PD 118,576 proved to be related to the bafilomycins and therefore is a new member of this recently discovered family of macrolide antibiotics.
\end{abstract}

During the course of our antitumor screening program a complex of antitumor macrolide antibiotics was isolated from the fermentation broth of an unidentified Streptomyces (WP 3913). The major component of this complex, PD 118,576, was found to exhibit in vitro activity against L1210 lymphocytic leukemia and HCT-8 human colon adenocarcinoma cell lines. The characteristics of the microorganism and the fermentation conditions used to produce PD 118,576 will be reported separately. This paper describes the isolation, properties, and structure determination of PD 118,576 which was found to be a novel 16 -membered macrolide closely related to the bafilomycins ${ }^{1,2)}$ and the L-681,110 complex of antibiotics ${ }^{3)}$.

\section{Experimental}

HPLC Analysis of PD 118,576

All HPLC assays for PD 118,576 were performed using a $\mu$ Bondapak C-18 column $(3.9 \mathrm{~mm} \times$ $30 \mathrm{~cm}$, Waters Associates), with $\mathrm{MeOH}-0.05 \mathrm{M} \mathrm{NH}_{4} \mathrm{OAc}$ buffer ( $\mathrm{pH} 6.5$ ) (70: 30) as the mobile phase at a flow rate of $1.5 \mathrm{ml} / \mathrm{minute}$, and detection by UV absorption at $254 \mathrm{~nm}$. The retention time of PD 118,576 in this system is approximately 5.0 minutes. The concentration of PD 118,576 in fermentation broths was assayed by extracting $25 \mathrm{ml}$ of unfiltered beer at $\mathrm{pH} 6.5$ with two $25 \mathrm{ml}$ portions of EtOAc. The combined extracts were evaporated to dryness and the residue was dissolved in $10 \mathrm{ml}$ of EtOH to afford a solution which was used for HPLC analysis after filtration through a $0.45 \mu \mathrm{m}$ filter. At 93 hours of fermentation, the concentration of PD 118,576 in broths was approximately $18 \mu \mathrm{g} / \mathrm{ml}$.

\section{Isolation}

Fermentation broth (57 liters, $\mathrm{pH}$ 6.3) was stirred with 30 liters of EtOAc for 30 minutes. Celite $545(3.2 \mathrm{~kg})$ was added and the mixture was filtered. The lower aqueous layer was separated and extracted with a 30-liter EtOAc wash of the filter cake. The organic layers were combined, washed with $\mathrm{H}_{2} \mathrm{O}$, and concentrated in vacuo to $300 \mathrm{ml}$. This concentrate was added, with stirring, to 4 liters of heptane $-\mathrm{MeOH}-\mathrm{H}_{2} \mathrm{O}$ (10:9: 1). The resulting mixture was filtered and the aqueous $\mathrm{MeOH}$ layer was evaporated to dryness in vacuo to yield $17.5 \mathrm{~g}$ of residue. $\mathrm{A} \mathrm{CHCl}_{3}$ solution $(75 \mathrm{ml})$ of the crude concentrate was chromatographed over $680 \mathrm{~g}$ of Silica gel 60 (E. Merck, 40 63 $\mu \mathrm{m}$ ) using increasing amounts of $\mathrm{MeOH}$ in $\mathrm{CHCl}_{3}$. All of the PD 118,576 was eluted in the 96: $4\left(\mathrm{CHCl}_{3}-\mathrm{MeOH}\right)$ fractions as determined by HPLC and TLC (E. Merck Silica gel 60 plates: Rf 0.30 , using $\mathrm{CHCl}_{3}$ $\mathrm{MeOH}$ (96:4); Rf 0.31, using EtOAc-heptane (7:3)). Concentration of these fractions in vacuo afforded $1.45 \mathrm{~g}$ of an oily residue. This material was further purified by chromatography over $120 \mathrm{~g}$ of Silica gel 60 (E. Merck, 20 40 $\mu \mathrm{m}$ ) using EtOAc - hexane (6:4) as the eluent. The fractions con- 
Table 1. NMR assignments for PD 118,576 in $\mathrm{CDCl}_{3}$ *.

\begin{tabular}{|c|c|c|}
\hline Position & ${ }^{1} \mathrm{H}$ NMR & ${ }^{13} \mathrm{C} \mathrm{NMR}$ \\
\hline 1 & & 166.5 \\
\hline 2 & & $141.3^{a}$ \\
\hline $2-\mathrm{OCH}_{3}$ & $3.67, \mathrm{~s}$ & 60.1 \\
\hline 3 & $6.63, \mathrm{~s}$ & $133.1^{\mathrm{b}}$ \\
\hline 4 & & $142.9^{\mathrm{a}}$ \\
\hline $4-\mathrm{CH}_{3}$ & $1.98, \mathrm{~d}(1.1)$ & 14.0 \\
\hline 5 & $5.75, \mathrm{~d}(9.0)$ & 142.4 \\
\hline 6 & $2.52, \mathrm{ddq}(1.2,7.0,9.0)$ & 36.8 \\
\hline $6-\mathrm{CH}_{3}$ & $1.07, \mathrm{~d}(7.0)$ & $17.4^{\mathrm{c}}$ \\
\hline 7 & 3.29 , br m** & 81.2 \\
\hline 8 & $\sim 1.88, \mathrm{~m}$ (obsc.) & $39.8^{\mathrm{d}}$ \\
\hline $8-\mathrm{CH}_{3}$ & $0.94, \mathrm{~d}(6.3)$ & 10.7 \\
\hline $9 a$ & 1.95, m (obsc.) & $41.3^{d}$ \\
\hline $9 b$ & 2.11 , br d & \\
\hline 10 & & 132.9 \\
\hline $10-\mathrm{CH}_{3}$ & $1.91, \mathrm{~s}$ & 20.0 \\
\hline 11 & $5.79, \mathrm{~d}(10.6)$ & 125.3 \\
\hline 12 & 6.47 , dd $(10.6,15.0)$ & $132.8^{\mathrm{b}}$ \\
\hline 13 & $5.15, \mathrm{dd}(9.0,15.0)$ & 127.0 \\
\hline 14 & $3.80, \mathrm{dd}(8.3,9.0)$ & 83.3 \\
\hline $14-\mathrm{OCH}_{3}$ & $3.21, \mathrm{~s}$ & 55.7 \\
\hline 15 & 5.03 , dd $(1.3,8.3)$ & 76.3 \\
\hline 16 & 2.05, m (obsc.) & 38.5 \\
\hline $16-\mathrm{CH}_{3}$ & $0.95, \mathrm{~d}(6.9)$ & 21.8 \\
\hline 17 & $3.73, \mathrm{~m}$ (obsc.) & 72.7 \\
\hline 18 & $2.95, \mathrm{dq}(4.2,7.0)$ & 46.5 \\
\hline $18-\mathrm{CH}_{3}$ & $1.21, \mathrm{~d}(7.0)$ & 10.3 \\
\hline 19 & & 203.1 \\
\hline 20 & $6.26, \mathrm{~d}(1.3,15.8)$ & 129.1 \\
\hline 21 & 6.82 , dd $(8.1,15.8)$ & 148.4 \\
\hline 22 & $2.39, \mathrm{dq}(1.3,6.7)$ & 44.0 \\
\hline $22-\mathrm{CH}_{3}$ & $1.08, \mathrm{~d}(6.8)$ & $14.6^{\mathrm{c}}$ \\
\hline 23 & $3.75, \mathrm{~m}$ (obsc.) & 70.7 \\
\hline 24 & $1.15, \mathrm{~d}(6.4)$ & 20.4 \\
\hline \multirow[t]{2}{*}{$\mathrm{OH}$} & $3.61, \mathrm{~d}(5.8)$ & \\
\hline & 1.57, br d $(6.4)$ & \\
\hline
\end{tabular}

* NMR spectra were recorded at $300 \mathrm{MHz}$ for ${ }^{1} \mathrm{H}$ and $75 \mathrm{MHz}$ for ${ }^{13} \mathrm{C}$. Chemical shifts are given in ppm downfield from TMS. $J$ values, in $\mathrm{Hz}$, are given in parentheses. Indicated assignments $(\mathrm{a}, \mathrm{b}, \mathrm{c}, \mathrm{d})$ are interchangeable. obsc. $=$ obscured (overlapping signals).

** Doublet observed after addition of $\mathrm{D}_{2} \mathrm{O}$. taining PD 118,576 as determined by TLC were combined and concentrated in vacuo to afford $736 \mathrm{mg}$ of PD 118,576 as a viscous oil. This product was $98.5 \%$ pure by HPLC and gave a single spot in the two TLC systems described above: UV $\lambda_{\mathrm{max}}^{\mathrm{MoOH}} \mathrm{nm}(\varepsilon) 244(28,230)$ and 284 $(10,500)$; IR $\left(\mathrm{CHCl}_{3}\right) 3620,3480,1705$ (sh), 1691, $1648,1625,1109$ and $1095 \mathrm{~cm}^{-1} ;[\alpha]_{\mathrm{D}}-6.5^{\circ}(c$ $0.17, \mathrm{MeOH}) ; \mathrm{EI}-\mathrm{MS} m / z 576\left(\mathrm{M}^{+}\right), 544,420$, $391,351,334,250,225,191,183,181,169,151$, $137,125,124,112,109,93$ and $83 ;{ }^{1} \mathrm{H}$ and ${ }^{13} \mathrm{C}$ NMR data are listed in Table 1.

\section{Acetylation of PD 118,576}

A solution of PD $118,576(10 \mathrm{mg})$ in $1.0 \mathrm{ml}$ of pyridine $-\mathrm{Ac}_{2} \mathrm{O}(1: 1)$ was allowed to stand at room temp for 21 hours. Volatile components were removed with a stream of $\mathrm{N}_{2}$ and the residue was chromatographed on a $20 \times 20 \mathrm{~cm}$ preparative TLC plate (E. Merck, Silica gel 60, $0.5 \mathrm{~mm}$ ) using EtOAc-hexane $(6: 4)$ as the mobile phase. The major TLC band, visualized under UV light, was removed and eluted with EtOAc to yield a tri- $O$-acetyl derivative $(6 \mathrm{mg})$ which was homogeneous in two TLC systems: UV $\lambda_{\max }^{\mathrm{MeOH}} \mathrm{nm}(\varepsilon) 242(36,800)$ and $281(13,500)$; IR $\left(\mathrm{CHCl}_{3}\right)$ 2965, 2933, 1730, 1708 (sh), 1628, $1457,1375,1101,1022,975$ and $912 \mathrm{~cm}^{-1} ;[\alpha]_{\mathrm{D}}$ $-15.1^{\circ}$ ( c 0.205, MeOH); EI-MS $m / z 702\left(\mathrm{M}^{+}\right)$, $642,582,376,347,332,316,241,217,191,151$ and $109 ;{ }^{1} \mathrm{H}$ NMR $\left(200 \mathrm{MHz}, \mathrm{CDCl}_{3}\right) 2.01,2.02$, $2.15(3 \times 3 \mathrm{H}, \mathrm{OAc}), 4.74(1 \mathrm{H}, \mathrm{dd}, J=2.4,6.1$, $\mathrm{H}-7), 4.87(1 \mathrm{H}, \mathrm{dq}, J=6.4,6.4, \mathrm{H}-23)$ and 5.19 $(1 \mathrm{H}$, obscured $\mathrm{m}, \mathrm{H}-17)$.

\section{Structure Determination}

A molecular ion is observed in the electron impact mass spectrum of PD 118,576 at $\mathrm{m} / \mathrm{z}$ 576 , corresponding to a molecular formula of $\mathrm{C}_{33} \mathrm{H}_{52} \mathrm{O}_{8}$. UV absorption maxima in methanol appear at 244 and $284 \mathrm{~nm}$ which indicate that PD 118,576 may be assigned to the class of macrolide antibiotics possessing an isolated con-

jugated diene and $\alpha, \beta, \gamma, \delta$-unsaturated lactone functionalities. This class includes both 18 -membered lactones (concanamycins ${ }^{4 \sim 6)}$ and virustomycin ${ }^{7)}$ ) and 16-membered lactones (bafilomycins ${ }^{1,2)}$, hygroli$\operatorname{din}^{5,8)}$, leucanicidin ${ }^{10,11)}$, L-115,175 ${ }^{12)}$ and the L-681,110 complex $^{3)}$ ). Comparison of the ${ }^{1} \mathrm{H}$ NMR spectrum of PD 118,576 (Table 1) with the corresponding signals reported for bafilomycin $\mathrm{A}_{1}$ (2), L$681,110 \mathrm{~A}_{1}$ (3) and related compounds revealed that PD 118,576 possesses the same 16-membered lactone moiety. This was further confirmed by analysis of fragmentation patterns in the mass 
A<smiles>C=CC(C)C(C)O</smiles>

B<smiles>CC(C)C(O)C(C)C</smiles>

C
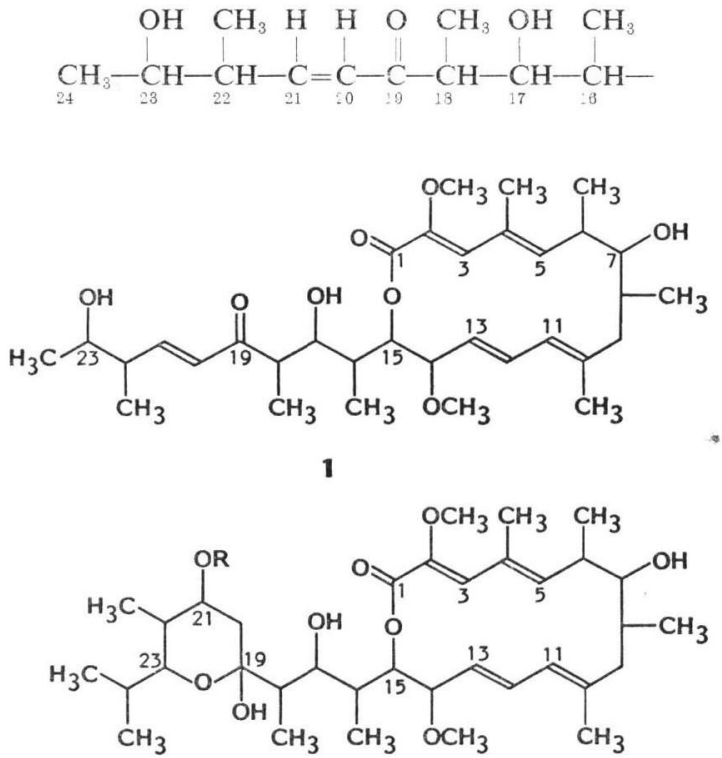

$2 \mathrm{R}=\mathrm{H}$

$3 \mathrm{R}=\mathrm{COCH}=\mathrm{CHCOOH}$

$t$<smiles>CC=C[C@@H](OC)C(OC(=O)/C(=C/C(C)=C/C(C)C(O)=C(CC)C(O)C(C)/C=C(C)/C=C/C)OC)C(C)C(O)C(C)C(=O)/C=C/C(C)C(O)/C=C/C</smiles>

spectrum of PD 118,576 in which the same fragment ions assigned to the macrolide portion of L$681,110^{3)}$ are also observed.

The structure of the remaining portion of PD 118,576 was readily discerned by analysis of the ${ }^{1} \mathrm{H}$ and ${ }^{13} \mathrm{C}$ NMR signals that distinguish this compound from the known antibiotics of the same class. The results of homonuclear and heteronuclear correlation NMR experiments suggested the presence of partial structures $\mathbf{A}$ and $\mathbf{B}$ which could be expanded to fragment $\mathbf{C}$ by the following arguments. A downfield signal at $203 \mathrm{ppm}$ in the ${ }^{13} \mathrm{C}$ NMR spectrum could be assigned to an $\alpha$, $\beta$-unsaturated ketone functionality, which was further confirmed by a shoulder in the IR spectrum at $1705 \mathrm{~cm}^{-1}$ and a positive reaction with 2,4-dinitrophenylhydrazine. The presence of an $\alpha$, $\beta$-unsaturated aldehyde was ruled out by the absence of a downfield signal in the ${ }^{1} \mathrm{H}$ NMR spectrum. Attachment of fragments $\mathbf{A}$ and $\mathbf{B}$ to the ketone carbonyl as shown is justified on the basis of coupling constants and chemical shift data. The olefinic proton signals at 6.26 and $6.82 \mathrm{ppm}$ (fragment $\mathbf{A}$ ) are consistent with the $\alpha$ - and $\beta$-protons of the $\alpha, \beta$-unsaturated ketone moiety, while the signal at $2.95 \mathrm{ppm}$ (fragment $\mathbf{B}$ ) must be assigned to the $\alpha^{\prime}$-proton. The proton connectivity from $\mathrm{H}-18\left(\mathrm{H}-\alpha^{\prime}\right)$ to $\mathrm{H}-15$ of the macrolide 
is clearly revealed by the homonuclear correlation data, thereby allowing the attachment of fragment $\mathbf{C}$ to the macrolide ring. The placement of hydroxyl groups at C-17 and C-23 was verified by the sharpening of the signals at 3.73 and $3.75 \mathrm{ppm}$ upon addition of $\mathrm{D}_{2} \mathrm{O}$, and their downfield shifts to 5.19 and $4.87 \mathrm{ppm}$, respectively, upon acetylation. Homonuclear spin decoupling experiments with the acetylated derivative confirm the indicated proton assignments, completing the assignment of structure 1 to PD 118,576. Additional verification of the side-chain structure is obtained by comparison of the ${ }^{1} \mathrm{H}$ NMR chemical shift and coupling data reported for similar protons in the alkaline degradation product (4) of concanamycin $\mathrm{A}^{4)}$.

\section{Discussion}

PD 118,576 represents the first example of a bafilomycin-type macrolide lacking a hemi-ketal ring in the side chain. The presence of a trans double-bond precludes the formation of the usual tetrahydropyran moiety. The possibility that PD 118,576 is an artifact produced during the isolation procedure can be excluded since the compound is readily detected in fermentation broths by HPLC analysis. PD 118,576 is only weakly active against most bacteria and fungi. However, the $\mathrm{IC}_{50}$ values for PD 118,576 against L1210 lymphocytic leukemia and HCT-8 human colon adenocarcinoma cell lines are $1.4 \times 10^{-8} \mathrm{M}$ and $1.1 \times 10^{-6} \mathrm{M}$, respectively.

\section{Acknowledgments}

We thank Dr. Christopher Rithner for his assistance in obtaining NMR spectra and Dr. JoAN SHILLIS and her group for tissue culture data. This work was supported in part by contract NO1-CM-37614 awarded by the National Cancer Institute, USA.

\section{References}

1) Werner, G.; H. Hagenmaier, K. Albert, H. Kohlshorn \& H. Drautz: The structure of the bafilomycins, a new group of macrolide antibiotics. Tetrahedron Lett. 24: 5193 5196, 1983

2) Werner, G.; H. Hagenmaier, H. Drautz, A. Baumgartner \& H. Zähner: Metabolic products of microorganisms. 224. Bafilomycins, a new group of macrolide antibiotics. Production, isolation, chemical structure and biological activity. J. Antibiotics 37: 110 117, 1984

3) Hensens, O. D.; R. L. Monaghan, L. Huang \& G. Albers-Schönberg: Structure of the sodium and potassium ion activated adenosinetriphosphate inhibitor L-681,110. J. Am. Chem. Soc. 105: 3672 3679, 1983

4) Kinashi, H.; K. Someno, K. Sakaguchi, T. Higashijima \& T. Miyazawa: Alkaline degradation products of concanamycin A. Tetrahedron Lett. 22: 3857 3860, 1981

5) Kinashi, H.; K. Someno, K. Sakaguchi, T. Higashijima \& T. Miyazawa: Structure of concanamycin A. Tetrahedron Lett. 22: 3861 3864, 1981

6) Kinashi, H.; K. Sakaguchi, T. Higashijima \& T. Miyazawa: Structures of concanamycins B and C. J. Antibiotics 35: 1618 1620, 1982

7) Ōmura, S.; N. Imamura, K. Hinotozawa, K. Otoguro, G. Lukacs, R. Faghih, R. Tolmann, B. H. Arison \& J. L. Smith: The structure of virustomycin A. J. Antibiotics 36: 1783 1786, 1983

8) Seto, H.; H. Akao, K. Furihata \& N. Ōtake: The structure of a new antibiotics, hygrolidin. Tetrahedron Lett. 23: 2667 2670, 1982

9) Corey, E. J. \& J. W. Ponder: Stereochemistry of the hygrolidins. Tetrahedron Lett. 25: 4325 4328, 1984

10) Isogai, A.; S. Sakuda, S. Matsumoto, M. Ogura, K. Furihata, H. Seto \& A. Suzuki: The structure of leucanicidin, a novel insecticidal macrolide produced by Streptomyces halstedii. Agric. Biol. Chem. 48: $1379 \sim 1381,1984$

11) Meyer, M.; W. Keller-Schierlein, H. Drautz, W. Blank \& H. ZäHner: Bafilomycin A, $21-O-(\alpha$-Lrhamnopyranoside): Structure determination by chemical correlations with bafilomycin $\mathrm{A}_{1}$ and leucanicidin. Helv. Chim. Acta 68: 83 94, 1985

12) Goetz, M. A.; P. A. McCormick, R. L. Monaghan \& D. A. Ostlind: L-155,175: A new antiparasitic macrolide. Fermentation, isolation and structure. J. Antibiotics 38: $161 \sim 168,1985$ 